\title{
On Crossing Lines and Going Between: An Interview with Marjorie Beaucage
}

\author{
Lynne Bell and Janice Williamson
}

\section{Traverser les lignes et aller au milieu: Entrevue avec Marjorie Beaucage}

Marjorie Beaucage est cinéaste, enseignante en art et vidéaste activiste installée à Saskatoon. Son travail artistique, qu'elle a commencéà 40 ans, est fondé sur des habiletés développées au cours des 25 ans qu'elle a passés comme enseignante pour adultes et organisatrice communautaire; ce qui crée chez elle un sens puissant de la création de l'art comme pratique communautaire. Elle a fait des documentaires sur la participation des fermmes aborigènes dans des conférences féministes nationales et internationales, rassemblements des aînés, blocus indigènes, et événements communautaires locaux. En plus de ce travail collectif, des vidéos plus personnels explorent son sentiment de chagrin personnel, perte et récupération dans Bingo (1991), un film sur l'inceste, et Good Grief (1993), un "film-maison" qui explore le deuil de sa famille lors de la mort d'un jeune frère.

Cette entrevue fait partie d'un projet de recherche de collaboration interdisciplinaire: "West of Where? Contemporary Prairie Women's Cultures." ("À l'est d'où? Cultures contemporaines des femmes des Prairies"). Beaucage parle de son oeuvre en tant que cinéaste explorant la culture aborigène, et en tant qu'activiste luttant pour que les voix des autochtones soient reconnues et financées par les institutions culturelles du Canada. Avec une exploration politique profonde de l'économie et de la politique de la culture canadienne et du mouvement des femmes au Canada, Beaucage décrit comment son travail vidéo est soutenu, appuyé, et influencé par la culture des femmes aborigènes.

Marjorie Beaucage is a Saskatoon-based Métis filmmaker, art educator and video activist. Our interview is part of a collaborative interdisciplinary research project "West of Where?: Contemporary Prairie Women's Cultures." In discussing our project with us, Beaucage pointed out that 
our category "prairie women" does not include the women who live and work in the northern non-agricultural bush region. Her work is equally particular about her understanding of the specificity of community documenting aboriginal women's participation in national and international feminist conferences, gatherings of elders, indigenous blockages, and local community events. As well as this collective work, more personally inflected videos explore her sense of private grief, loss and recovery in Bingo (1991), a heavily coded incest film, and Good Grief (1993), a "home movie" exploring her family's mourning at the death of a younger brother. Her artistic work begun at the age of 40 builds on skills developed over 25 years as an adult educator and community organizer creating a powerful sense of art making as communal practice.

Lynne: I've noticed that in your videos the camera work stresses a shared communal space rather than hierarchical space that is created in conventional cinema, where the focus is on the heroine or hero. Can you talk about how you have developed your own filmic language to express Aboriginal storytelling forms?

Marjorie: Well I think a good storyteller takes a story, puts it out in a community context and leaves room for the other person to tell their own. stories, whether it's the viewer or someone listening. So while you are watching or listening, you make your own story in your head. You're always working with energy and making space for people to figure things out for themselves. It has to do with respecting that everybody has something to offer, and knowing that you're not the only voice. The principle of storytelling is relationship; there is no hierarchy, every voice is worth listening to.

Janice: In Our Living Treasures (1993), a documentary of an elders gathering at Wiggin's Bay in Northern Saskatchewan, what I really liked was how the elongation of time gave one a sense of the duration of work process, duration rather than simply the cultural product. For example, in making a paddle out of a tree trunk, the elder worked to the heart of the matter literally - the heart of the tree trunk eventually gives the paddle its strength. All of this was accomplished with an ax, a delicate tool in his hands at the same time as the artist told a wonderful story. 
Marjorie: Well time and space are relative. There is no absolute time or space. What's in the present holds everything, from behind and ahead. So you have to leave room.

Janice: Yesterday you said that none of your work has cost more than $\$ 3,000$ to produce. Your first film Bingo [1991] was financed by a chain letter and a pot luck. I can imagine finances would be a limitation. Or do budget limits provide an alternative method of working?

Marjorie: No, I don't see it as necessarily a good thing. I'd like to work full time at what I do, but I can't because of financial things. So I always use a Robin Hood approach to earn my living. I'll take a few contracts or do lectures that will subsidize my real work so I can pay my bills. For every artist, there's stress worrying about paying the rent when the end of the month comes along, though this doesn't prevent me most of the time. I always find a way if I really want to do something, although I never did finish the blockade film [Protectors of Mother Earth]. That was a really hard one. The Elders asked me to come and I left Toronto to land in Wiggin's Bay where I stayed in a tent for six months with a borrowed camera, some tapes and two batteries, to film their struggle to protect the North Saskatchewan forest against clear cutting. Over the course of the two years the blockade was up, I went back and forth collecting stories and feelings about what was happening to the people and the land. That was very discouraging because the government forced them into a catch-22 situation. They took the Elders to court for a million dollars each and then said they wouldn't negotiate anything until they left the blockade. The Elders counter-sued the government for not doing an environmental assessment and then they had to make a choice of continuing with their suit or keeping the blockade. Since the Elders didn't trust the courts, they dropped the case although I think they would have won it. In the end, the companies and political leadership sold them out anyway. So there are no more negotiations or blockade and everybody has been pretty well bought off. The companies and the government had their way. I would like to do a video on that whole process because we are still so colonized. It's a tough one because nobody really wants to fund that kind of story and I don't have the resources to do it the way I would like to.

Janice: How do you deal with the process of defeat. You call your film Good Grief [1993] a healing medicine film and I can see how it is a thera 
peutic exploration of the private and collective grief of your family around the loss of your brother. But how do you deal with the kind of despair that must come from the frustrations around the blockade?

Marjorie: You don't: it's grist for the mill. You don't package things all up and it's over. It's always there, but you can't stay there in that despair. That's why I create because otherwise it would do me in. It would do anybody in. It does a lot people in. Look at the suicide and the alcohol. All those things come from that place of feeling powerless.

Lynne: There is such an ethos of cultural resistance in your videos. And the very format of the video allows it to be taken around to various communities to be used as a teaching tool. Do you see yourself as a teacher engaged in social change?

Marjorie: I think change is possible. When you look at situations, you've got to be able to see not just the problems, but the possibilities. If you can spark one little person to act, to stand up - it's worth it. I've been doing that all my life for myself. All the work I've done is about change and the possibility of doing it together. My life has been group-centered in that sense because to work alone is defeating. That's why we started the Aboriginal Film Video Art Alliance. We were all struggling with these things on our own and coming up against closed door after closed door. Your head starts to hurt, bashing them in or trying to sneak in the back way. So we decided to help each other in whatever ways we could to keep doing the work in spite of the industry pressures in film and television in particular.

We made the Alliance to protect our stories and to lobby to change policies. It takes a long time at Canada Council, but now when somebody applies to do an aboriginal story there's a provision that if they don't have the permission of the community, they won't get to do it. Just small changes maybe, but they took years. You know the whole debate in the writers' community in the late seventies and eighties around cultural appropriation. It's not resolved but we made some changes in the Writers' Union in terms of putting a few motions on the floor. Even though Margaret Atwood and Pierre Berton and all those guys resisted it, we still managed to have these matters discussed. Those are the battles we have to do; otherwise people don't even know what they are doing. It gets tiring: that part gets really tiring - you spend all that energy that 
you could be putting it into your work. By working collectively, we take turns going on the front lines as it were. When you take a break, somebody else is there: whereas before we were all isolated and burnt out. I haven't burnt out for a while.

Lynne: You held the position of Runner at The Banff Centre for the Arts from 1993 to 1995. Can you tell us about this position which I understand involved developing Aboriginal arts programming at Banff?

Marjorie: As a Runner I was always negotiating, making room or protecting our space so we could create together. I was like the bouncer between the institution and the projects; whenever there was a problem I was troubleshooting. When I got to Banff there was one of me and all of them - all the departments and their protocols and this and that, so I really had to figure out how Banff worked. The various disciplines don't talk to each other though they started to have management meetings when their funding was starting to get cut. But they are all very protective of their little turfs and their disciplines, and their dollars, and their scholarships. I figured that out. The first year we did a series of public service announcements [PSAs On Self-Government, 1994] because the Media and Visual Arts section of Banff were the most open to having us. While I was working on the PSAs, I went to each department about the next year because we were just getting leftovers. We didn't have priority time or space. Whenever there was a gap we filled it that first year.

The Alliance works with existing groups. We negotiated a Banff residency for the Native Theater School which has been in existence for twenty-five years and still has no funding base unlike the National Theater School which has always had core funding. Even though every year the Native Theater School has to apply for project dollars, they still create the Graham Greens and the Gary Farmers and the Tantoo Cardinals. We've never had core funding for any of our arts.

The first winter theatre residency was for senior artists who teach and train new people but don't have time to develop their own methodology or cultural form in a more disciplined way. Winter was the time when theatre was down, music was down, and Banff didn't have programmes. So I said, "Okay let's put something in each of those programmes." I had a couple of media projects as well. Come winter the second year, a hundred people were there. All of a sudden Banff was crawling with Indians. They didn't know what to do with us, you know? All of a 
sudden, they are being invaded right! Whoa. There was so much racism on campus - the staff and everybody. It was pretty bad. But we had a good winter because there was a community and all this exchange between disciplines and people. So we decided to have a winter camp and set priorities every year. We wanted to look at new technologies, how they are going to serve us or not, and how to design our own system. There was always someone working on that. Then we decided we should have a summer project because Banff is full of musicians, opera and theater because of summer tourists.

Lynne: You participated in "Aboriginal Women's Voices," a Banff residency in traditional singing?

Marjorie: We sang every day and decolonized our voices. Sadie Buck was the teacher and she put out a call and invited certain people - 10 women, including four senior women from different nations and young ones. Every morning we had to sing and open ourselves and then make up our own songs. We only sang social songs, not sacred songs. We taught each other songs and planned and designed a concert at the end. The residency was a project for Sadie to develop more of a methodology for teaching traditional singing, and for exchanging methodologies with other people who were teaching women's songs, and social songs in different nations - the different structures of songs, different rhythms, the different sounds from different places.

Janice: You've been pointing out some of the limitations of Banff, but were there people who facilitated your work? You cited video artist Vern Hume as a consultant on your video Good Grief [1993].

Marjorie: Well, he helped me with the technology. But what Banff has to learn is that we have spent a lot of time learning their protocols, but they haven't learned ours yet. Every time we do a project, we teach them. Some are more open than others to learning; theater and music are the most closed disciplines in the world, the most entrenched in their forms and formulas as far as aboriginal stuff goes. Media, visual arts, and performance are more open to change. There is more room there so we've been more successful in those disciplines. Although now, it's getting harder because of the cuts. But every time we go to Banff, we have to train their people to work with us. 
Janice: You work a lot with children's voices, stories or songs. They resonate all through your work and in your first film Bingo [1991]. Those moments of childhood allow you to reflect on the anxieties as well.

Marjorie: Well, memory and history are all part of that place too. Youth, kids, old people are teachers, you can learn a lot from them. In terms of social change, youth and women are the most likely to change things although they have the least power in the world. Youth, women and old people are always present in my life. The first five years of your life are the most formative. Going back to that place to remember is where the real truth lies. That's where your truth stems from and so it seems normal for me to go there because society has abandoned that place you know. It doesn't allow people to be in that place, even children - they are all little adults by the time they start school. The messages that you learn at home are about your place in the world and your relationship to things.

Lynne: A sense of the family frequently appears as a liberated zone in your work, as part of the need to decolonize what has gone on.

Marjorie: Yes. I've always ranted and raved at systems and I will until I die. Some individual change and transformation is possible, but social systemic evil is a harder one because it's in everything from what you eat to how your food gets to you.

Janice: Another zone of safety for me in my work is provided by female friendships. You've worked closely with a number of women on various projects. In your video China....through one woman's eyes [1996], there is an invocation of friendship and activism.

Marjorie: Yes, well like I said, women are the most willing, ready and able to change. They have always been my allies and supports in whatever I have undertaken. You can always count on your friends. I'm fortunate since I have had lots of good friends along the way to walk with me. I can't imagine not having them. Grandmothers are always sending you people to learn from and walk with. I love women, always have, always will, because they are mirrors: you recognize yourself in their strengths and their weaknesses. 
Janice: Do you see allies in the Women's Movement?

Marjorie: Well, what is that? We struggled with that in Beijing.

Janice: Whether it's singular or plural?

Marjorie: Yes, because the Women's Movement as it is defined by feminist academic theory is often a very closed system, very classist and mostly racist because it doesn't recognize cultural difference. I've had a very hard time with it. Did you see Wings of The Same Bird [Making the Links: Anti-Racism and Feminism 1993], that I did about the feminist CRIAW conference [Canadian Research Institute for the Advancement of Women] in Toronto? Anyway, cultural values are different in a Black community, Aboriginal community, Chinese community. I learned that when I was in the Philippines in the 1980s and saw the people struggle for their liberation against the Marcos regime. I saw the role women played in that struggle and how the Women's Movement tried to influence Bagriela, the women's sector in the Philippines, to take certain stands. But when your children are hungry and you don't have running water and you know you're fighting for health, because you're dying of diarrhea, it's not a Women's Movement issue you know. The Women's Movement doesn't take on things like hunger and the need to keep a family together:I don't think they respect family and different structures of decision making. Women's conferences are the most patriarchal events that I still go to. They don't know what a Circle is and what real equality is. We could teach them a lot and I've tried. Every single conference I've been to since 1970, it's the same thing, they haven't learned anything: they still have panels and one-way communication, and this guest star thing. If it's truly a Women's Movement, they should have learned by now that's now how women talk to each other. I've complained about these things all along the way, and I hang in there - I was with NAC [National Action Committee] at Beijing. Some friends have recognized some of these things but still there's a long way to go because their politics, their strategies, their whole protocol are all male and patriarchal. They haven't created truly feminist forms. Their analysis is in a male model, especially an academic model. Some women try to break out but as a movement it doesn't appeal to me. It's not where I feel comfortable and myself. There is no room for me there. I don't like to debate, because that's a win lose situation, not an exploration. We're not 
there because it is not welcoming. A lot of us individually have tried at different times to participate, but they never come to participate in our Circles, our gatherings or events - it's always one way. We have to go to their events, their turf but they don't come to ours. That's the only way they are going to know the difference. Say if the NAC President comes to town, why do we all have to go to her meeting? Why can't she come and sit in our Circle?

Janice: A white friend, a poet, just came back from a gathering at the E'nowkin School of Native Writing in Penticton where she felt very welcomed by the women who knew her. But at other moments she also felt very self-conscious and out of place, like an invader. I wonder if part of the reticence isn't a feeling that you're going to actually interrupt something by your presence.

Marjorie: That's always the case for us. We're always in a strange land. I don't think the Circle is unfriendly or unwelcoming. If she felt that way, that was her stuff because there is always room. You take your place: nobody takes it away from you. If you are sitting in the Circle, you take your place not anyone else's. If there's room for you, you can speak from your place and you are in relationship with everybody else. Now if that makes you uncomfortable, that's your right. My responsibility when I'm sitting in the Circle is to speak from my place, from my truth, and I say what I need to say. If I'm uncomfortable then I say that - that's what selfgovernment is. If I'm hurting, then I say that. I cannot speak for you or anyone else. My second responsibility in the Circle is to listen and respect what other people are saying. If I have something else to say when my turn comes again, because something someone said touched me or raised a question, then I'd put it out. That's the structure of self-government-the Circle.

Janice: Do you have a women's Circle here in Saskatoon?

Marjorie: There are lots, all kinds - like the healing initiative and all kinds of Circles within that one. And then there are smaller artists' Circles. Last winter we just got together once a month and made quilts and talked. Our only rule was that we couldn't talk about work. [laughter] You call a Circle when you need it because that's your responsibility. In the Alliance, we used to have once-a-month potlucks. Each Circle is 
self-governing so it's not like an umbrella organization or a collective. So there is Saskatoon, Toronto, and Vancouver - the different groups they do their own thing. Circles change for different purposes.

Janice: I was involved in the Women's Peace Movement in the 80 's where we organized ourselves as affinity groups which were structured in part according to your traditional Circles. We were arrested for non-violent civil disobedience actions against the Canadian production of the cruise missile guidance system. Our organization proved to be a very subversive strategy because the police could not find our "leader" or who was responsible for this and that because each group was very selfcontained.

Marjorie: Yeah, that's why it's hard for us to get Canada Council funding because they demand that you are incorporated. How do you incorporate a Circle? When we are together in a Circle we are incorporated more in our bodies, you know. I told the Canada Council: "This is who we are. There are twenty-five of you around this table and there's one of me. Now you guys figure out how to do what we want to do. That's your job - you're the bureaucrats hired to do that."

Janice: And what was their response?

Marjorie: Well, we're starting to get more grants! When the Canada Council changed Explorations Grants, they gave us a portion of those dollars for our budget!

Lynne: And monies also came from the Art Bank...

Marjorie: Yeah, because they shut that down as well. We have been lobbying and working for change, but their forms are not very userfriendly. As a jury member I certainly don't find them helpful. Why does everybody have to fit their project into that form when it doesn't fit? A lot of our projects are interdisciplinary! Why can't you just put your vision forward - what you want to do, why you want to do it, how much it's going to cost? Joane Cardinal-Schubert is a visual artist who can't get video funding because she has never made a video. It's stupid. I can't be a producer because I've never produced. I figure, "Hell! Give me a million bucks and I'll show you what producing means!" 
Janice: You are producing a feature for the first time?

Marjorie: Yes the Rougarou story from the Qu'appelle Valley written by Joe Welsh, directed by Loretta Fodd, and starring.... [laughter] We have a wish list but we have to have stars to get a distributor. All these rules.

Lynne: So you have to have a star system?

Marjorie: Well not for the first round! I mean in order to get through those funding doors, I have to go hunting for an executive producer, someone who will walk me through the business to satisfy those guys so we can get the money. And then it'll be hands off on the creative end.

Lynne: Have you had to modify your film script to satisfy your financial backers?

Marjorie: We've had our film script trashed a hundred times already by story editors at Telefilm who have never heard of the Métis or a Rougarou. They changed our wonderful lyrical love story into a horror movie!

Lynne: That's pretty telling isn't it?

Marjorie: Yes, because the film is a cross between the X-Files and Like Water for Chocolate.

Janice: That sounds fantastic! Is it full of magic realist elements?

Marjorie: Well, you know the Rougarou is a story about a werewolftype character. In French they call them Loup Garou. Let's say you were bad, maybe your life went off track. How do you get back on? Sometimes it takes drastic measures. The Rougarou has to come.

Lynne: In filming this story will you incorporate the digressions and meanderings that are customary in the oral tradition?

Marjorie: The actual Rougarou story that I just told you occurs in the middle of the film when the old man comes to school for career days. The only reason he tells the story at that time is because the Rougarou is going 
on around the community. By the time you hear the story you can figure out the movie.

Lynne: Whereas conventional cinema tends to spill the beans early on!

Janice: It would be completely enraging to have your collective work travestied by Telefilm...

Marjorie: It's been three years! And we've been fighting to protect the story. Finally we said, "We'll take the project back because there is no leadership - it's not going to happen." I ended up being the producer. I never set out to be a producer for feature films but I know I can do it. I didn't want to be the Runner, but I had no choice. At a Canada Council meeting for the Alliance in Banff, everybody agreed we needed someone who would be the go-between for the Banff Centre and the community. I wasn't asked. Someone said, "Marjorie will do it" and everybody said, "yes". They had a feast and gave me that responsibility and I did it. It took less than two years to do the work. It's the same with this producer business. It was never my ambition to be a producer of feature films but I thought, "I'm going to giveit a shot-my best shot-I haveall the skills and more to put the team together and carry the vision forward!" It's just organizing and I've been doing it all my life. So what's a million bucks? If you can budget with nothing, you can budget with a million. It's the same difference. The figures don't scare me.

Janice: In your article on video ["Aboriginal Voice: Entitlement Through Storytelling" in Mirror Machine: Video in the Age of Identity, ed. Janine Marchessault, Toronto: YYZ, 1995], you talk about anger as a "creative energy behind the stories."

Marjorie: Well, it's part of everyone's work. I mean we all have it whether you destroy or create with it, it's up to you. I don't ever want to lose this energy, it propels me forward and moves things out there. If you turn it in and cover it up with despair, you're going to be dead.

Lynne: So much of your work is what you call creative documentary, about the gatherings, conferences and blockades of various Aboriginal communities. 
Marjorie: To me they are moments in time where people are gathering to change things or to understand things, or to take actions of some kind or another.

Janice: This notion of creative documentary, especially when I think about your China video where there is a movement between inner and outer, between an imaginary story and historical document...

Marjorie: There's nothing fictive in my work.

Janice: But digging all the way to China seems...

Marjorie: No, that's not fiction.

Janice: Isn't it an imaginative journey?

Marjorie: It's my first memory of China. This is how I got this cut right here [gestures to her hand], I was digging with a tin can in the sand at home. That's what my Grandma said: "Be careful you're going to dig all the way to China!" There was this idea that China was on the other side of the earth and you could literally dig your way through there. That really fascinated me. So to me, that's not fiction because it was my first awareness of China. I don't call that imagination or fiction. I'm just grounded in a very real moment in my life.

Janice: For me it's a cultural fiction, an imaginative act.

Marjorie: Well, the sun coming up in the morning is a cultural fiction that still exists, even though Galileo said over five-hundred years ago that the earth was round, that paradigm shift hasn't occurred yet. The sun coming up every day isn't a cultural fiction because if you really believed Galileo when you got up in the morning, you would say "the earth has turned."

Janice: Would you see any relationship between your notion of creative documentary and someone like Myrna Kostash whose writing works to createa Ukrainian-Canadian history of migration and settlement? While it is clearly a different history, some of the formal innovations seem similar. 
Marjorie: Well, that's the trouble with words and labels, isn't it? If you see creation as a central act of everything and the most sacred thing anyone can do - (that's what I mean when I say creation - to give life to something) - to me it's not a fiction or in my imagination, but a very concrete act. When I'm documenting history, I'm creating this moment in time. It's sometimes like re-construction, de-construction, re-creation - those are all parts of that moment in time. If I think about memory and my ancestors behind me, and about the future that I'm making by doing this - what's behind the future - then it's all part of the moment. So I hate labels. I hate trying to define it. I'm not objective according to the conventions of documentary because I put myself in the work. And it's not cinema verité although a lot of it is. My work isn't easily categorized.

I was shocked that in this film world business, the product is so important, because for me it's a process and how I got there that's important. Bingo was my first experience and I was not prepared for it at all. It's like you gave birth to this thing, my first born. And then it's out there and has a life of its own. All of a sudden you have to talk for it, but I said, "no, I took care of it, I brought it out, there it is and it talks for itself." I had all these battles because they said it wasn't a Native film because it wasn't about Native people, and [the National Film Board's] Studio D said it wasn't a woman's film because there were men in the bingo hall. They wouldn't help me finish it when I tried to get help. They said, "Why don't you go shoot on the Res?" I never have and I never will because that's not me and besides I'm in Six Nations territory and I want to live.... [laughter] I don't live on the Res. All these people wanted to decide how or what I was supposed to put in my film even before it was born, never mind after. And in the film festivals, it wasn't considered a documentary. The footage is cinema verité and it doesn't have a conclusion. I went to film. school, learned from people and worked full-time on this film working things out. I wanted to see what I could do - if this was me or not, but when I was finished all of a sudden I had to deal with all of these other questions.

Janice: I really love the sound in Bingo.

Marjorie: Yes, that's my little dig at the church. It was the Berlioz Requiem. My original idea was to structure the whole thing like a mass. But that was too didactic and obvious. I recut that film about twenty-five 
different ways. There is a ritual element to Bingo and I wanted to choose music that would respect the people and not laugh at them, so it had to be something big. I thought of opera but then I was looking through stuff in the library and I saw that Berlioz was very sacrilegious because it was a quadraphonic symphonic Requiem Mass and nobody had ever done that before. So I figured, if he can take the Requiem Mass and do that to it, then he won't mind if I put it in my film! [laughter]

With Bingo I watched a lot of silent film and thought how controlling the form was with sync sound. I didn't want to shoot in sync. Sound is a good place to work for the resonance of the piece. Sound has vibrations and is used to manipulate emotions in film. Sound is also one of the elements in the story. The oral storyteller uses different voices at different times for different things. It's not just one sense ever. You have your inner voice and the voices of the land - the trees and the environment around you are characters. It's amazing how much a voice can tell. I remember when I came back from the Philippines and tried to do slide shows. I don't like photographs that dramatize poverty. I thought the only way to do it was to pack the room with people, turn the thermostat up, get two guys in uniform to let the people in and set out twenty-five bags of garbage. They don't have scratch and sniff movies but they should have a track on the movie that would let you smell the place you're in. Sound can help you do this.

Janice: I'm curious about how incest survivors read Bingo since it is such a subtle film.

Marjorie: Bingo still is the piece of work that I love in terms of it being mine. For the three years I worked on the film, I didn't care about anything else except the process I was in and finding my way through this victim thing. There's more to life than surviving-I'm a warrior. I've shown Bingo at a conference for incest survivors. They were shocked but I said, "This is my medicine. This is better than any therapy I've ever done. I don't know of any therapy that ever caused a revolution. You're never going to heal if you keep picking at your scabs."

Bingo was first started by the church as a fund-raiser for the rich and it wound up a lottery for the poor. Now bingo is the opium of the people. If there weren't any bingo, there wouldn't be poverty, because it pacifies everyone. The oppressors are in the Bingo Hall. That's the metaphor. Money and class. And then there's chance, fate and luck - what nobody 
can control and what makes people lucky. I was in the Bingo Hall for six months filming and every Sunday afternoon we would have all these conversations.

I premiered the film in that hall and the players were all stars for that day. My Mom came down from Manitoba to Ontario to the film premiere. She didn't know what I was doing. She knew I was in film school but was worried about me being in Toronto. She gave me a little card with a picture of a little girl and a pig at a country fair that said, "You're a winner."

Lynne: Did your mother understand the incest part of Bingo....

Marjorie: Aboriginal people get a lot of stuff nobody else gets. They don't have trouble understanding my films. The film leaves room for other people's stories. Good Grief is similar. When I first showed it at the Nomad Banff Centre Residency, the feedback I got was that it was about loss and relationship. We stayed in that room after the screening for two and a half hours while people told their own stories of loss and grief.

Lynne: In my own Anglo culture, there is a fear of staying in the grief.

Marjorie: After my brother died, I went home and asked my family if they would do the film with me. I just asked them how they spent their year after my brother's death and they gave me their trust. I wanted to explore how you find your place in a family of twelve people and what it is like to be in grief, to wake up every day with only bits and pieces of things. I made the piece for my family and gave them copies of the tape. I had no intention of putting it into distribution, but my sister entered it in a Winnipeg film festival. When the festival called saying they wanted a copy of the tape, I thought they meant Bingo. But they said no, they wanted Good Grief, and, "...by the way, are you coming to the screening?"

"I guess I have to," I said. I have a certain presence in Winnipeg where I worked in adult education most of my life. Everyone I had ever known came out and the screening was sold out. It was the first time we saw it on the big screen and they had to show it twice. There were Kleenex boxes on both ends of the rows.

When I was asked to show it at the festival, at first I thought this was a stupid idea. I didn't shoot it as a video. I thought maybe I should just use the voices and make it as an audio tape. The video is in the audio. I 
saw it more like a home movie, and then I thought, "This will be the best goddamn home movie...."

Lynne: There is a tradition of activist indigenous film making in Canada. I'm thinking of Alanis Obamsawin's and Loretta Todd's films. Your films also reconstruct cultural memory and critique on-going neo-colonial relations in society. Can you talk about this tradition of sociallyconscious film and video?

Marjorie: Well, if you are going to create from where you are, we haven't got a choice. We want to do other things too. There are things that need to be said and done and you have that responsibility. But it's not a tradition. Different people express in different ways. There are three of us making these kind of films, but it's not exactly a tradition. When you look at all the other work being made, ours is a minority voice even in our own community. So far, film has not been a very accessible door since it costs a lot of money and the only filmmakers able to get into the NFB door have had to fight for every single frame that ends up on the screen.

Janice: Lynne and I watched Ann Wheeler's film Loyalties again last night. The ending seemed so peculiarly wistful, a fantasy moment in feminist history where an illusory sisterhood could erase all differences between an upper-class English woman and a Métis woman played wonderfully by Tantoo Cardinal.

Marjorie: Well, its all about POV [point of view] isn't it? If the story was told from the other side's perspective, Native history wouldn't be a footnote at the end in a way that dismisses all the differences and what makes everyone special and unique. For its time, Loyalties is one of the better pieces that is out there, a good role for Tantoo. She doesn't get too many contemporary parts.

Janice: You talked yesterday about the limits of the term postcolonialism. Your perspective was very critical.

Marjorie: We're very, very much in a colonial world and who said it was postcolonial? It's even more dangerous when you think it's over. The Elders say, "We'll tell you when it is postcolonial." It took five hundred years to get here and it's going to take another five hundred years to 
become un-colonial. The colonial world is worse than ever because we have internalized so much. We have to de-colonize our minds, systems, schools, everything. The whole system hasn't changed since it was invented.

Janice: Does two-spiritedness play a role in your work?

Marjorie: It's again like feminism. You know you're a woman and you're two-spirited. It's part of who you are. People don't care who you sleep with or who you love, as long as you're a good person. So it doesn't play a part in my work. I haven't made a "lesbian" work, just like I haven't made a "woman's" film. I make films. I actually got programmed in a New York lesbian festival called Not Queer Enough. [laughter] I said, "Yeah, you can program my work." My film work goes to all these different places everywhere because I've always crossed lines and gone between. So two-spiritedness is a part of me, not any more or less than that. It's never been an issue.

Lynne: I have been really struck by the attention to language in your videos. Can you talk about this?

Marjorie: Well, language and voice have always been an important part of my work. In Land Solidarity \& Healing [1993], I experimented with voice and several languages. Instead of using subtitles I used different forms to communicate. I usually send out transcripts of the text in the video box and when I have a public screening I say to the people, "Listen to the person not the words and hear what they are saying. If you feel like you need it translated, here is a handout. Look at it when you need to, otherwise just take it to meditate on when you go home." When you talk in your own language, it's a different way of thinking of being that comes from a different place. A language is a world view and you can't really translate that although you can translate the words as best you can. When I did the China piece, I didn't have the original soundtrack but I tried to leave the people's voice. Most documentaries take away the voice especially when they are about us. They have this voice-over narration that tells you what that person is saying instead of letting the people speak for themselves. I want to let the people speak for themselves. I want to be heard the way they are, in that moment. And at the same time, you want people to listen and get when you're doing. 
Lynne: In your video on China you talk about the Three Gorges Project and the flooding of the Yangtze River which will displace so many people and swallow up the land forever. Is a coalition politics important to you?

Marjorie: You recognize that no matter where you go, you see people and situations through your own eyes. In China I was travelling alone and had my own preoccupations about land, people, development and the megacorporations running the world. But the more allies the better. That's why the Indigenous Women's Network at the Fourth World Conference on Women in Beijing was so great because there were seventy-four nations from all over the world and we didn't have to explain ourselves to each other. That was the good part about being in Beijing.

Lynne: Will you make a separate documentary on the conference?

Marjorie: Well I have no soundtrack for it. I really feel bad about that, especially for the Indigenous Women's Network because I had fully expected to do a video just on that since I was the only one in our tent with a camera and people were very generous, sharing their stuff with me. I don't know what I'm going to do. I think I've learned my lessons here. The first lesson was in the reconstruction of the film and the second lesson was that I did it too fast. So maybe that's all that video was for. I can now take those learnings and put them in my next piece. It's never going to be perfect anyway.

Lynne: Can you tell us about your upcoming work with the Innu community in Labrador?

Marjorie: It looks like it's a go and we will probably start working in January. There are all kinds of minerals and resources in the Innu territory in Labrador. Sheshatshiu and Davis Inlet are the two most affected communities. Sheshatshiu has already had to deal with assault from the NATO low-level flight bombing range testing. The Boisey Bay Nickel Company and INCO have already been doing open-pit mining there. And there are one hundred and sixty-eight more claims in Labrador. The Innu people have been negotiating with the company about how development should occur on their lands and want to do their own study on their traditional land use using video as a form of their oral history. 
Janice: How did you begin to make films. It's your mid-life career isn't it?

Marjorie: I've always been interested in art. I learned the guitar and the fiddle and did popular theatre for five years. But film is where it all came together. At forty years old, I ran away from home to Toronto and Ryerson. I was working in literacy at the time and had been doing groups and adult education work for about 25 years. I was finding myself getting impatient, thinking things were never going to change. My coworker knew I was at the end of the line during an eight-hour drive to Le Pas with a lot of time to talk: she asked, "What would you do if you could do anything you wanted?"

I said, "Don't laugh, but I would like to become a dancer," — though I knew my body would not be able to do it. I talked about how I used image and story in my education work and my co-worker said "What about film? Movies?"

Right then Isaid, "I love movies but" — and I told her how I was a total techno-peasant and anti-technology. I thought I would never learn it. After listening to all of my objections, she said, "You're in adult education. What would you say to me if I were saying this to you?"

That night I was lying in bed and every time I thought about making films, this big smile would come on my face in the middle of the dark. So one day I said to Joanna, "Where do you learn film?" There wasn't any place in Winnipeg but her brother was at Ryerson. I hadn't been to school for 25 years but Joanna helped me put my portfolio together because I didn't know how to do it. I got accepted at Ryerson, though I never graduated. We were supposed to do a drama before graduation, but I just did what I needed to do to learn what I needed.

Janine Marchessault was the only teacher at Ryerson who was interested in listening to me. I wrote my own film theory in a chapter for the video book and she said, "I'm not asking you to write like me. I want to hear your voice in the book."

Right now I'm only 50 and I've got another 40 years to make films. I think I have four or five good ones left in me. When you get to be a grandmother, when the moon doesn't visit any more, that is the power timethe best time to be a woman because you can do everything a woman can do and everything a man can do too. 